Jurnal Bimbingan Konseling
$10(1)(2021): 14-21$
UNNES

\title{
The Counseling Group of Anger Management and Social Skills Training Techniques to Reduce Physical Aggression Behavior
}

\author{
Era Annisa Emansi Saliha ${ }^{凶}$, Mungin Eddy Wibowo, Awalya Awalya \\ Universitas Negeri Semarang
}

\begin{abstract}
Article Info
Abstract

History Articles

Adolescent development aspects that must be attain in overcoming problems Received:

10 January 2021

Accepted:

22 February 2021

Published:

30 April 2021 are having emotional maturity, intellectuality and awareness of social responsibility so it is not to trigger new conflicts. However, the reality is conflict that often occur in dealing with a problem tend to appear negative behavior, especially physical aggressive behavior. This study aims to examine the effectiveness of group counseling of anger management techniques and social skills training techniques to reduce physical aggression in junior high

Keywords:

Anger management, social skills training, physical aggressionbehavior school students. A total of 21 students were involved in experimental research using randomized pretest posttest comparison group design. The analysis of the results of Wilcoxon and Kruskal Wallis shows that group counseling of anger management techniques, social skills training techniques and a combination of the two techniques are effective in reducing students' physical aggression behavior. Combining anger management and social skills training group counseling techniques are more effective in reducing students' physical aggression behavior compared to the self-management technique group and social skills training. This study recommends the integration of anger management techniques and social skills training techniques to reduce physical aggression in junior high school students.
\end{abstract}

\footnotetext{
Correspondence address:

Gedung A Kampus Pascasrjana UNNES

J1. Kelud Utara III Semarang 50237

E-mail: eraannisaemansisaliha@gmail.com
}

p-ISSN 2252-6889 


\section{INTRODUCTION}

Junior high school students are generally aged 11-15 years according to their developmental tasks at this age is a transitional period, where students seek their identity through emotional, cognitive, social and behavioral aspects. Emotional maturity, intellectuality, awareness of social responsibility, independence and personal development are some aspects of development that students must master during this transitional period (Kemdikbud, 2016). During the period of selfsearch, there are socio-emotional changes in adolescents, including demands for independence, trying to know oneself, and trying to meet the demands of the environment which is very rapidly changing (Indarjo, 2009; Monk in Hapsari, 2013; Santrock in Pamungkas, 2016).

Hidayati (2017) suggests adolescents do something without thinking twice, even though they know the risks to be faced, especially in managing the emotions they feel. Conflicts that often occur in dealing with a problem tend to appear negative behavior. One of the negative behaviors shown by adolescents is aggressive behavior, which is any behavior aimed at other individuals which is carried out with the direct intention of causing ruining or harm (Genn 2001, Anderson \& Busshman 2002). Experience of aggressive behavior is shown through various forms of behavior such as berating, cursing, fighting, rioting, robbery, murder, and all kinds of criminal and violent behavior (Susantyo, 2011; Efastri, 2015; Salmiati, 2015).

Physical aggression that occurs at school can occur if students have low emotional maturity. Students do not understand how to express feelings naturally and appropriately based on contextual and do not understand various expressions in feelings of themselves and others. Most physical aggression peaks towards peers (Rowell, 2018). Such as hitting objects or friends, pushing, deliberately destroying items to expel their emotions, throwing objects, and so on.

The counselors are very important in helping students to have good behavior. One strategy that counselors can use to assist students in directing behavior is by providing techniques when providing counseling services. The techniques used to assist students in reducing physical aggression are anger management techniques and social skills training techniques.

The anger management helps students with high levels of aggression learn how to manage, control and help express their emotions in appropriate ways (Report, 2013, Mehta \& Sagar 2015). The anger has been identified as a strong risk factor for violence at school, especially when it culminates in sudden anger (Report, 2013). The anger management techniques can help aggressors become more aware of their emotions and show more reactions that are appropriate in different situations. The changing negative schemes and cognitive reconstruction that leads to decreased experiences of anger can reduce the expression of anger by aggressive behavior (Vatankhaah, 2013).

The research conducted by Feindler (2011) using anger management techniques is effectively used to reduce anger and aggression in adolescents which includes physiological, cognitive and behavioral training. Several studies have also shown that adolescents who acquire anger management skills through group sessions not only gain anger control skills but can also significantly reduce aggressive behavior (DiGiuseppe \& Tafrate, 2003; Snyder et al., 1999; Valizadeh et al., 2010; Vatankhaah et al., 2013). However, a study conducted by Watt \& Howells (1999) on 50 perpetrators of violence using the STAC anger management program showed no significant changes between the experimental and control groups. This occurs due to 4 substantive factors; there are low participant motivation, poor program integrity, insufficient program time, and absence of screening assessments.

The impact of aggressive behavior does not only affect children's function in emotional and behavioral development, but it also affects academic achievement, their social interactions with peers and teachers (Salmiati, 2015). In 
addition, students who have aggressive behavior often show inhibiting abilities to empathize with others (Feindler, 2011), exhibit underdeveloped social skills, which can lead to social isolation, withdrawal and anxiety (Glick in Feindler, 2011)

The social skill training is a technique that can be used to solve social problems. Babhakani (2011) mentions that adolescents, who are irritable and aggressive, judge themselves negatively, rare communication, often require social skills training.

The several studies have shown that social skills training can significantly reduce aggression (Akbari et al, 2012; Alavi, Savoji, \& Amin, 2013) and overcome many emotional disorders (Spence, 2003). However, evidencebased research conducted by Taylor (1999) shows that interpersonal skills training conducted in adolescents is limited in the short term and does not reduce behavior in the long term. Babakhani (2011) found that SST was effective in reducing verbal aggression but there was no significant difference in physical aggression between the control and experimental groups.

The one of the strategies that counselors can do to help students reduce physical aggression is by providing services in groups to students. The service used in this study was the CBT group counseling

The group counseling is a process of problem-oriented assistance provided to members to find strengths to overcome problems arising from dynamic interactions in groups (Corey, 2012). CBT therapy tries to change the mindset that is important in client problems (Jeri Fires, 2002) so that the things the client finds to be the cause of anger may not be the cause anymore. CBT is one of the most effective psychological interventions. Through counseling groups or psycho-educational groups it has been shown to reduce aggressive behavior and bullying in the school environment (Horne, Stoddard, \& Bell, 2007) and group CBT therapy is effective in reducing aggression in 24 addicts in Tehran (Najafi 2016)
This study is intended to test CBT group interventions with anger management techniques and social skills training techniques to reduce students' physical aggression. Through the provision of CBT group counseling services, anger management techniques and social skills training techniques are thought to reduce students' physical aggression behavior.

\section{METHODS}

The experimental subjects were 21 students who had high physical aggression behavior category which were selected from 162 students. They were placed into 3 experimental groups consisting of 7 students in each group.

The scale used in this study is a physical aggression behavior scale developed by researchers based on Yudofsky's (1986) physical aggression theory. Physical aggression includes physical aggression against self, against object and against other people. The AGF scale consists of 43 items with the results of all instrument test items declared valid (rxy: 0.2890.623 ) and having a cronbach alpha coefficient of 0.737 .

The data analysis technique used in this study was the Wilcoxon test and Kruskal Wallis test on the gain score of each group. The research method used was an experimental research method using experimental design "randomized pretest-posttest comparison group design".

The experimental procedure was carried out in several stages. First, giving the AGF scale pre-test. Second, providing treatment / intervention in the form of counseling for group 1 CBT (anger management) with 5 sessions for group 1, (social skills training) with 5 sessions for group 2 and (a combination of anger management and social skills training) 5 times for groups. 3. The duration of each group is 80 minutes. Finally, the measurement after treatment or post test with the AGF scale. The systematic of the group counseling activities for the anger management technique and social skills training will be described in table 1 . 
Table 1. Systematic Activities of anger technique and social skill training

\begin{tabular}{|c|c|c|}
\hline Section & Anger Management (AM) & Social Skills Training (SST) \\
\hline 1 & $\begin{array}{l}\text { Building cohesiveness and formulate } \\
\text { the goals }\end{array}$ & $\begin{array}{l}\text { Building cohesiveness and formulate the } \\
\text { goals }\end{array}$ \\
\hline 2 & $\begin{array}{l}\text { Discussing the concept of anger and } \\
\text { identify anger and feelings that arise }\end{array}$ & $\begin{array}{l}\text { Identifying emotions and feelings that } \\
\text { arise, understand the strengths and } \\
\text { weakness of yourself }\end{array}$ \\
\hline 3 & $\begin{array}{l}\text { Identifying signs of anger and response } \\
\text { with positive thought }\end{array}$ & $\begin{array}{l}\text { Identifying signs of anger and responses. } \\
\text { Learning basic skill to communicate } \\
\text { (body language) with positive thoughts. }\end{array}$ \\
\hline 4 & Exploring anger management strategies & Problem solving \\
\hline 5 & Evaluating of results and following-up & Evaluating of results and following-up \\
\hline
\end{tabular}

Furthermore, group counseling combines two techniques, namely building cohesiveness, identifying anger, exploring anger management strategies, understanding one's strengths and weaknesses, body language, problem solving, evaluation of results and follow-up.

\section{RESULTS AND DISCUSSION}

The data in this study shows the average level and standard deviation of physical aggression behavior in the experimental group before the intervention, namely in group A management techniques $(\mathrm{M}=156.71 ; \mathrm{SD}=$ 9.09), counseling group $B$ with social skills training techniques $(\mathrm{M}=15.71 ; \mathrm{SD}=8.62)$. While group $\mathrm{C}$, a combination of management techniques and social skills training $(\mathrm{M}=$ 155.85; SD $=9.79$ ) The complete results are presented in table 2 .

Table 2. The Result of the Effectiveness of Technical Group Counseling, Anger Management, Social Skill Training and Combining Anger Management, Social Skill Training

\begin{tabular}{lllccl}
\hline \multirow{2}{*}{ Group } & \multicolumn{2}{l}{ Pre-test } & \multicolumn{4}{c}{ Post-test } & \multirow{2}{*}{$\mathrm{Z}$} \\
\cline { 2 - 5 } & Mean & SD & Mean & SD & \\
\hline Kel. AM & 156.71 & 9.09 & 111.43 & 11.29 & $-2.37^{*}$ \\
Kel. SST & 157.71 & 8.62 & 124.57 & 15.18 & $-2.37^{*}$ \\
Kel. AM + SST & 155.85 & 9.79 & 102.00 & 13.47 & $-2.38^{*}$ \\
$\chi^{2}(2)$ & .136 & & $6.97^{*}$ & & \\
\hline${ }^{*} \mathrm{p}<0.05 \quad{ }^{* *} \mathrm{p}<0.01$ & & & & &
\end{tabular}

The effectiveness of group counseling with anger management techniques, social skills training and a combination of both in reducing students' physical aggression behavior was tested by wilcoson, the results of which are presented in table $2(\mathrm{Z}=-2.37 ;-2.37 ;-2.38, \quad \mathrm{p}<0.05$; respectively). These results indicate that the management technical group counseling, social skills training and a combination of the two are effective in reducing students' physical aggression.
Based on the results of the Kruskal Wallis test, it was found that there were differences in the effectiveness of anger management techniques, social skills training and a combination of both on reducing students' physical aggression behavior $(\chi 2(2)=6.97$, $\mathrm{p}<0.05)$.

Thus, the Mann Whitney test must be carried out to measure the difference in the effectiveness of each technique in reducing students' types of physical aggression. The 
results of the Mann Whitney test in this study show that the counseling group anger management technique is more effective than the social skills training technique $(Z=-1.86$, $p=<0.05$ ). Furthermore, the combining group of the two techniques is more effective than social skill training $(Z=-2.37, p<0.05)$. while the anger management group has no significant difference from the combaining group of anger management techniques and social skill training $(Z=-1.15, \quad p>0.05)$. The whole results are presented in the table 3 .

Tabel 3. Mann Whitney Test

\begin{tabular}{lll}
\hline Group & $\mathrm{Z}$ & $\mathrm{P}$ \\
\hline Kel. AM - SST & -1.86 & $<0.05$ \\
\hline Kel. AM - (AM+SST) & -1.15 & $>0.05$ \\
\hline Kel. SST - (AM+SST) & -2.37 & $<0.05$ \\
\hline \multicolumn{1}{l}{ Note: } & \\
$\quad$ AM: Anger Management; SST: Social Skills Training; AM+SST: Combining Anger Management \\
Technique and Social Skills Training
\end{tabular}

These results indicate that the group counseling technique of anger management and social skills training is effective in reducing physical aggression behavior of junior high school students.

This study analyzes group counseling with anger management techniques and social skills training to reduce students' physical aggression behavior. The aim of effectiveness is to obtain an overview of the extent to which counseling group interventions with anger management techniques and social skills training are effective in reducing students' physical aggression behavior.

This anger management technique of counseling group aims to assist students in managing the anger experienced by students in dealing with everyday problems. This study analyzes the effectiveness of group counseling with anger management techniques to reduce students' physical aggression behavior. This research is in line with the research conducted by Siddqiah (2010); Valizedeha (2010); Feindler (2011); Akbari (2012) states that anger management techniques can reduce student's aggression behavior.

The social skills training technique counseling group aims to help students understand themselves and the environment around them so that the emotions that arise can be directed properly. This study analyzes the effectiveness of social skills training group- counseling techniques to reduce students' physical aggression behavior. This research is in line with research conducted by Babakhani (2011); Akbari et al (2012); Alavi, Savoji, \& Amin (2013) stated that social skills training techniques can reduce student aggression behavior.

As for what distinguishes this research from research conducted by Siddqiah (2010); Valizedeha (2010); Feindler (2011); Akbari (2012); Akbari et al (2012); Alavi, Savoji, \& Amin (2013) that in this study the research subjects were junior high school students, and the research was focused only on physical aggression. Whereas in the previous study, research was conducted with high school teenage boys (Sidqiah, 2010), preschool children (Valizedeha, 2010), prisoners (Akbari, 2012) addicts (Najafi, 2016) and the focus of the research was not only verbal aggression (Valizedeha, 2010; Babakhani, 2011; Feindler, 2011; Akbari, 2012; Akbari et al, 2012; Alavi, Savoji, \& Amin 2013; Najafi, 2016).

Based on the results of research, opinions and results of previous studies, it can be concluded that the group counseling of anger management techniques and social skills training is effective in reducing students' physical aggression behavior, so that the counselor can use the counselor to improve negative student behavior towards a more positive direction. In this study, group counseling with anger 
management techniques and social skills training was the most effective in reducing students' physical aggression, especially against self and against objects. Feindler (2011) emphasizes that anger management training which includes physiological training (identifying experiences of anger, relaxation), cognitive (cognitive restructuring) and behavior (role play), further training is social skills training, anger control training, and effective moral reasoning training. reduce anger and aggression behavior.

Anger management techniques direct students to express their anger appropriately by identifying the anger and its causes. In line with Pilania, Mehta \& Sagar (2015) that the purpose of an anger management program is not to make angry emotions go away, but to help express anger in a healthy and appropriate way. Through anger management, adolescents gain broader insight into the factors that trigger their anger and acquire tools that will help them express their feelings in a more appropriate way (Gabriel et al, 2014). By knowing the various causes and signs of anger as a trigger for physical aggression, through anger management techniques students can make decisions that need to be made to overcome problems related to physical aggression. After students can overcome their physical aggression behavior, students are expected to have a change in the right attitude in controlling their anger so that physical aggression behavior can be avoided.

Meanwhile, in social skills training techniques to reduce physical aggression behavior, a counselor directs students to know themselves and their environment better. Social skills can help them to know what to say (appropriate expression of feelings) and how to effectively choose and = behave in different situations (Spence, 2003). But in practice, the social skills training technique is still less effective when compared to the AM technique and the combined AM, SST technique. This is because the researchers themselves feel less optimal in providing the technique. So that children feel less optimal in getting treatment.
However, the findings of this study still have limitations in them. There is no follow-up to see the effect of timing in all three groups.

\section{CONCLUSION}

The research findings regarding the effectiveness of group counseling using anger management techniques and social skills training techniques to reduce physical aggression behavior, it can be concluded that there are differences in the level of effectiveness of the three groups in reducing students' physical aggression. The combining anger management and social skills training counseling group techniques are more effective in reducing students' physical aggression than the anger management technique in counseling group and social skills training group counseling.

Based on the findings in this study, it is suggested that counselors use group counseling techniques combined with anger management and social skills training in providing interventions to reduce physical aggression in junior high school students. For the further researchers, they have to focus more on taking subjects who have gender diversity and school levels.

\section{REFRENCES}

Akbari, B., Shahnam, A., Gholamreza, T., and Ali, D. (2012). Evaluate the effects of anger management skills training to reduce aggressive male prisoners. Journal of Basic and AppliedScientific Research. 2(9), 9590-9593.

Akbari, B \& Sadeghi, S. (2012). Eficacy social skills training and control techniques training decreasing of aggression behavior and impulsivity children parents to opiate abuse rasht city. Journal of Basic and Applied Scientiffic Research.2(2), 171 31717.

Alavi, S Z., Savoji, Azkar P., Amin, F. (2013). The effect of social skills training on aggression of mild mentally retarded children. ProcediaSocial and 
BehavioralSciences.84, $1166 \quad-1170$ doi:10.1016/j.sbspro.2013.06.720

Anderson, C A \& Dill, K E. (2000). Video games and aggressive thoughts, feelings, and behavior inthe laboratory and in life. Journal of Personality and Social Psychology. 78(4), $772-790$ doi: 10.1037//O0223514.78.4.77

Babakhani, N. (2011). The Effects of social skills training on self-esteem and aggression male adolescents. Procedia - Social and Behavioral Sciences 30, 1565-1570.

Corey, G. (2005). Teori dan paktek konseling dan psikoterapi. Bandung: PT Refika Aditama

Coyne, S, Nelson D dan Underwood. (2011). Aggression in Children. P. K. Smith and C. H. Hart (eds.) The Wiley-Blackwell Handbook of Childhood Social Development, Second Edition. New Jersey: Blackwell Publishing Ltd.

DiGiuseppe, R.,Froh, J. (2002). What cognitions predict state anger?. Journal of Rational-Emotive and Cognitive-Behavior Therapy. 20(2), 133-150. doi : 10.1023/A:1019835215935

Efastri, Rustono, Wibowo, M. E. (2015). Kefektifan konseling kelompok dengan pendekatan behavioral untuk mengurangi perilaku bullying dan perilaku agresif. Jurnal Bimbingan Konseling 4 (2), 114-120.

Feindler, Eva and Engel, E. (2001). Assesment and intervention for adolescents with anger and aggression difficulties in school settings. Psychology in the Schools 48(3), 243-253. doi: $10.1002 /$ plts. 20550

Geen, Russel G. (2001). Introduction to the study of Aggression. Human Aggression Second Edition. Philadelphia : Open University Press.

Gabriel, E \& Nelson, K. (2014). Destructive anger among adolescents: management strategies for principals and teachers. The Journal of Adventist Education. 6, 18-23

Hapsari, M., Fitri.,E Sri \& Ratri, D. (2013). Agresivitas ditinjau dari kontrol diri pada remaja pemain game online di kota semarang. Jurnal EMPATI. 2(4), 288-295
Hidayati, Mulawarman dan Awalya. (2013). Meningkatkan regulasi emosi siswa melalui layanan bimbingan kelompok dengan teknik sosiodrama. Indonesian Journal of Guidance and Counseling. 6(4), 27 $-34$

Horne, A. M., Stoddard, J. L \& Bell, C. D. (2007). Group approaches to reducing aggression and bullying in school. Group dynamics: Theory, research, and practice.11 (4), $262 \quad-\quad 271$. doi:10.1037/1089-2699.11.4.262

Huesmann, L. R. (2018). An integrative theoretical understanding of aggression : a brief exposition.Current Opinion in Psychology. 19, 119-124. doi: 10.1016/j.copsyc.2017.04.015

Indarjo, S. (2009). Kesehatan Jiwa Remaja. KEMAS: Jurnal Kesehatan Masyarakat, 5(1), 48-57. doi: 10.15294/kemas.v5i1.1860

Kemdikbud. (2016). Panduan Operasional Penyelenggaran Bimbingan Konseling Sekolah Menengah Pertama (SMP). Jakarta : Kemdikbud Dirjen GTK.

Najafi, M \& Khorasani. (2016). On the effectiveness of group cognitivebehavioral therapy on aggression in Addicts Research on Addiction Quarterly Journal of Drug Abuse. 9(36), 125-137.

Pamungkas, A. (2016). Studi tentang perilaku agresif siswa di SMP negeri se-kecamatan nganjuk. Jurnal Mahasiswa Bimbingan Konseling UNESA. 6(2), 1-9

Pilania, V. M., Mehta, M\& Sagar, R. (2015). Anger management. Mehta, $\mathrm{M} \&$ Sagar, R (eds.). A Practical Approach to Cognitive Behaviour Therapy for Adolescents. India : Springer

Report, T. (2013). Anger Management Tier. January 2016.2 doi: 10.13140/RG.2.1.2290.1841

Salmiati. (2015). Perilaku agresif dan penanganannya (studi kasus pada siswa smp negeri 8 makassar). Jurnal Psikologi Pendidikan \& Konseling. 1(1),66-76.

Siddiqah, L. (2010). Pencegahan dan penanganan perilaku agresif remaja 
melalui pengelolaan amarah (anger management). Jurnal Psikologi. 37(1), 50 64

Skiba, R., \& McKelvey, J. (2000). Anger management. Fact sheet. Lincoln, NE: Safe and Responsive Schools Project, Indiana University and University of Nebraska-Lincoln.

Snyder, K. V., Kymissis, $\mathrm{P}$ andKessler, K. (1999). Anger management for adolescents: efficacy of brief group therapy. Journal of the American Academy of Child and Adolescent Psychiatry. 38(11), 1409-1416.

Susantyo, B. (2011). Memahami perilaku agresif: Sebuah tinjauan konseptual. Informasi 16 (3), 189 - 202

Spence, S H. (2003). Social skills training with children and young people: Theory, evidence and practice. Child and Adolescent Mental Health 8(2), 84-96.

T. K. Taylor, J. M. E. and A. B. (1999). Interpersonal skills training to reduce aggressive and delinquent behavior: limited evidence and the need for an evidence-based system of care. Clinical Child \& Family Psychology Review, 2(3), 169-182

Valizadeh, S; Rahman,B; Ozouni,D; and Mitra, N. (2010). The effectiveness of anger management skills training on reduction of aggression in adolescents. Procedia Social and Behavioral Sciences. 5(1), 11951199

Vahedi, et al. (2007). The effect of social skills training on aggression of mild mentally retarded children. Iran J Psychiatry 2(3), 108-114. doi:10.1097/00004583199911000-00016.

Vatankhaah, H., Rahmani, M., \& Hashemizadeh, S. (2013). The Effectiveness of Cognitive-Behavioral Training on General Health and Reducing Aggression in Women with Premenstrual Syndrome. Contemporary Research Business, 4(9), 1098-1105.

Watt, B. D., \& Howells, K. (1999). Skills training for aggression control: Evaluation of an anger management programme for violent offenders. Legal \& Criminological Psychology, 4(2), 285-300.

Yudosfky, S. C., Silver, J. M., Jackson, W., Endicott, J., \& Williams, D. (1986). The Overt Aggression Scale: an operationalized rating scale for verbal and physical aggression. American Journal of Psychiatry, 143(1), 35-39 